\title{
Determination of the minimum inhibitory concentration of Quinolons for Salmonella typhi and Salmonella paratyphi
}

\author{
Malik Bhawna *, Sharma Kadambari* \\ * Dept. of Biotechnology, Govt. Madhav Science College, Ujjain (M.P.)
}

\begin{abstract}
Salmonella enterica serovars Typhi and Paratyphi are predominantly known to cause enteric fever. Multidrug resistance in S. Typhi and S. Paratyphi has emerged as a cause of concern. This study was done to evaluate status in antimicrobial susceptibility patterns of Salmonella enterica serovar Typhi (S. Typhi) and S. Paratyphi obtained from blood culture.

Multidrug resistant (MDR) strains of Salmonella enterica have emerged worldwide. Isolates of S. typhi with reduced susceptibility to fluoroquinolones have now appeared in the Indian subcontinent and other regions. However, in India the degree of resistance to commonly used antibiotics such as chloramphenicol, ampicillin and co-trimoxazole in the era of quinolone resistance is not clear.

In present study MIC and MDR\% for S.typhi and S.paratyphi for the Ciprofloxacin, Gatifloxacin and Levofloxacin were find out. Out of the total isolates studied, high level resistant for ciprofloxacin was 23 (58.97\%), Gatifloxacin 15 (38.46\%) and Levofloxacin was 0(0\%). At low level resistance \% of MDR for Ciprofloxacin was 14 (35.89\%), Gatifloxacin was 21 (53.84\%) and for Levofloxacin was 38 (97.43\%). Susecptibility for Ciprofloxacin was 2 (5.12\%), Gatifloxacin was 3 (7.69\%) and Levofloxacin was 1 (2.56\%). MIC value for Ciprofloxacin $8 \mu \mathrm{g} / \mathrm{ml}-<0.125 \mu \mathrm{g} / \mathrm{ml}$ was in between 0 to 16, for Gatifloxacin was 0-21 and for Levofloxacin was 0-14.
\end{abstract}

Key Words: Ciprofloxacin, Gatifloxacin, Levofloxacin, MIC, MDR\%.

\section{Introduction}

Bacterial infections constitute an important cause of morbidity and mortality among humans all over the world. For decades, antimicrobial drugs have proven useful for the treatment of bacterial infections. Although some bacteria are inherently resistant to even newly developed antimicrobial agents, the emergence of acquired resistance to antimicrobial drugs has been observed in almost all pathogenic bacteria. Antimicrobial resistance has become an important public health problem associated with serious consequences for the treatment of infection. This ultimately affects both economic and social development. The problem has been attributed to the misuse of antimicrobial drugs, which provide selective pressure, favoring the emergence of resistant strains[1].

Enteric fever remains an important public health problem in many countries of the world. Typhoid fever is a sometimes fatal infection of adults and children that causes bacteremia and inflammatory destruction of the intestine and other organs. Typhoid fever is endemic in developing countries. Chloramphenicol has been a choice of treatment for typhoid fever for about 40 years, but alternative drugs for treatment are now required by the emergence of multidrug-resistant (MDR). Fluoroquinolones have proven to be effective for the treatment of typhoid fever caused by MDR strain, and have become the drugs for the first line of treatment of typhoid fever[2].

The quinolones are a family of broad-spectrum antibiotics. The parent of the group is nalidixic acid. The majority of quinolones in clinical use belong to the subset of fluoroquinolones, which have a fluoro group attached the central ring system, typically at the 6-position.Resistance to quinolones can develop rapidly, even during a course of treatment. Numerous pathogens, including Staphylococcus aureus, enterococci and Streptococcus pyrogens, now exhibit resistance worldwide[3]. Quinolones and fluoroquinolones are bactericidal drugs, actively killing bacteria. Quinolones inhibit the bacterial DNA gyrase or the topoisomerase IV enzyme, thereby inhibiting DNA replication and transcription. Quinolones can enter cells easily and therefore are often used to treat intracellular pathogens such as Legionella pneumophila and Mycoplasma pneumoniae. For many gram-negative bacteria DNA gyrase is the target, whereas topoisomerase IV is the target for many gram-positive bacteria[4]. Quinolone antibiotics were once considered relatively safe, but several side effects have become evident with experience. Resistance to quinolones can develop rapidly, even during a course of treatment. Numerous pathogens, including Staphylococcus aureus, enterococci, and Streptococcus pyogenes now exhibit resistance worldwide.

Ciprofloxacin is an antibacterial drug. It is used to kill any bacteria in the body that are causing infection. It may be used for bacterial infection in patient with crohn's disease. It chemically attaches to the 
infecting bacteria and prevents their growth and multiplication. Ciprofloxacin is not effective against viruses, parasites or fungi.

Gatifloxacin is an antibiotic in a group of drugs called floroquinolones. It fights bacteria in the body. Gatifloxacin is used to treat bacterial infections of the lungs, sinuses, skin and urinary tract. It is also used to treat certain sexually transmitted diseases. It is an antibiotic of the fourth-generation fluoroquinolone family, that like other members of that family, inhibits the bacterial enzymes DNA gyrase and topoisomerase IV.

Levofloxacin is an advanced generation fluoroquinolone antibiotic. It is an antibiotics used to treat a wide variety of bacteria infection, including pneumonia sinusitis, urinary tract infections, acute bronchitis, and other type of infection .it acts by severely injuring the cell walls of the infecting bacteria, preventing them from growing and multiplying .This medication kills susceptible bacteria, but it is not effective against viruses, parasites, or fungi[5].

\section{Aim}

The objective of the present study is to determine the minimum inhibitory concentration of Quinolons for Salmonella typhi and Salmonella paratyphi.

\section{Materials and Methods}

In present study the test organisms were isolated from the blood of the infectious persons and then the agar dilution method were applied to determine the MIC and MDR \% for the test organism.

\section{Agar dilution Method}

MIC for quinoloes was determined by agar dilution method. Briefly a total of 39 (S.Typhi,S. Paratyphi.) isolates were subjected for MIC for quinolones....... quinolones powder with assayed potency was provided by Anusandhan laboratory, Indore, India. Stock solution of quinolones was made by dissolving $12 \mathrm{mg}$ powder in $5 \mathrm{ml}$ DMF. The concentration of quinolones used in the plate was in the range of $0.125 \mu \mathrm{g} / \mathrm{ml}$ to 8 $\mu \mathrm{g} / \mathrm{ml}$. Inoculum density was adjusted to $0.5 \mathrm{McFarland}$ standard. And it was diluted 1:10 approximately $10^{4}$ cells were deposited over 100mm Mueller Hinton Agar (Hi Media) plates. Results were read after overnight incubation. Colonies less than 10 were considered as no growth. The E.coli ATCC 25922 and, Kleb ATCC 700603 were included as control organism for each set of experiment.

\section{Observation}

\section{MIC values for Quinolons in $\mu \mathrm{g} / \mathrm{ml}$}

\begin{tabular}{|l|c|c|c|c|c|c|c|c|}
\hline & $\begin{array}{c}8 \\
\mu \mathrm{M} / 1\end{array}$ & $\begin{array}{c}4 \\
\mu \mathrm{M} / \mathrm{M} 1\end{array}$ & $\begin{array}{c}2 \\
\mu \mathrm{g} / \mathrm{M} 1\end{array}$ & $\begin{array}{c}1 \\
\mu \mathrm{g} / \mathrm{M} 1\end{array}$ & $\begin{array}{c}0.5 \\
\mu \mathrm{g} / \mathrm{M} 1\end{array}$ & $\begin{array}{c}0.25 \\
\mu \mathrm{g} / \mathrm{M} 1\end{array}$ & $\begin{array}{c}0.125 \\
\mu \mathrm{g} / \mathrm{M} 1\end{array}$ & $\begin{array}{c}<0.125 \\
\mu \mathrm{g} / \mathrm{M} 1\end{array}$ \\
\hline Ciprafloxacin & 1 & 16 & 6 & 13 & 1 & 0 & 1 & 1 \\
\hline Gatifloxacin & 0 & 0 & 0 & 16 & 21 & 1 & 0 & 1 \\
\hline Levofloxacin & 0 & 1 & 14 & 8 & 13 & 0 & 0 & 3 \\
\hline
\end{tabular}

\section{MIC values For Control organism in ug/ml}

\begin{tabular}{|l|c|c|c|c|c|c|}
\hline & \multicolumn{2}{|l|}{ Ciprafloxacin } & \multicolumn{2}{|l|}{ Gatifloxacin } & \multicolumn{2}{l|}{ Levofloxacin } \\
\hline & I & II & I & II & I & II \\
\hline E.coli & $<0.125$ & $<0.125$ & 0.5 & $<0.125$ & 0.25 & 0.25 \\
\hline Klebsella & 0.5 & 1 & 1 & 1 & 1 & 1 \\
\hline
\end{tabular}

$\%$ of MDR

\begin{tabular}{|l|ll|ll|ll|}
\hline & \multicolumn{2}{|l|}{ High level resistant } & \multicolumn{2}{|l|}{ Low level resistant } & \multicolumn{2}{|l|}{ Susceptible } \\
\hline Ciprafloxacin & 23 & $(58.97 \%)$ & 14 & $(35.89 \%)$ & 2 & $(5.12 \%)$ \\
\hline Gatifloxacin & 15 & $(38.46 \%)$ & 21 & $(53.84 \%)$ & 3 & $(7.69 \%)$ \\
\hline Levofloxacin & 0 & $(0 \%)$ & 38 & $(97.43 \%)$ & 1 & $(2.56 \%)$ \\
\hline
\end{tabular}



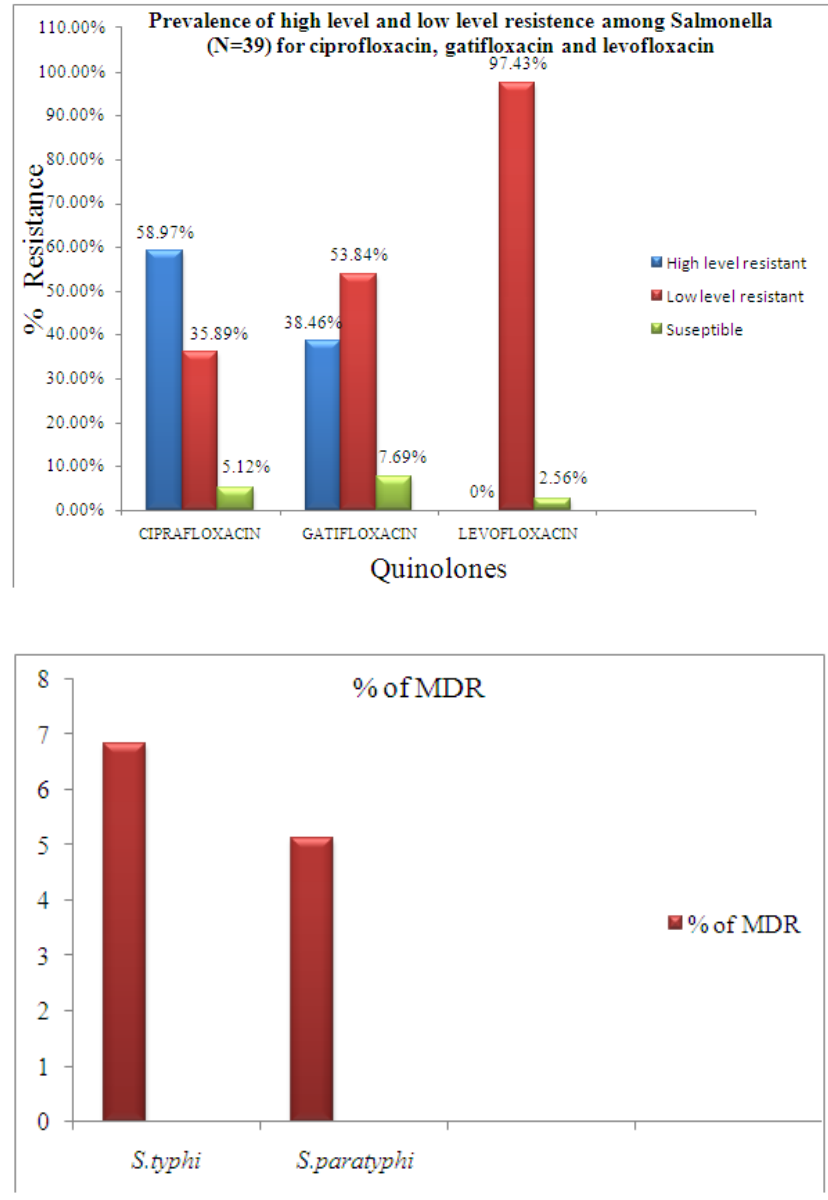

\section{Result and Discussion}

In present study MIC and MDR\% for S.typhi and S.paratyphi for the Ciprofloxacin, Gatifloxacin and Levofloxacin were find out. Out of the total isolates studied, high level resistant for ciprofloxacin was 23 (58.97\%), Gatifloxacin 15 (38.46\%) and Levofloxacine was 0(0\%). At low level resistance \% of MDR for Ciprofloxacin was $14(35.89 \%)$, Gatifloxacin was 21 (53.84\%) and for Levofloxacin was $38(97.43 \%)$. Susceptibility for Ciprofloxacin was 2 (5.12\%), Gatifloxacin was 3 (7.69\% and Levofloxacin was 1 (2.56\%).

MIC value for Ciprofloxacin was 0 at $0.25 \mu \mathrm{g} / \mathrm{ml}, 1$ at $8 \mu \mathrm{g} / \mathrm{ml}, 0.5 \mu \mathrm{g} / \mathrm{ml}, 0.125 \mu \mathrm{g} / \mathrm{ml}$ and $<0.125 \mu \mathrm{g} / \mathrm{ml}, 6$ at $2 \mu \mathrm{g} / \mathrm{ml}, 13$ at $1 \mu \mathrm{g} / \mathrm{ml}$ and 16 at $4 \mu \mathrm{g} / \mathrm{ml}$. MIC for Gatifloxacin was 0 at $8 \mu \mathrm{g} / \mathrm{ml}, 4 \mu \mathrm{g} / \mathrm{ml}, 2 \mu \mathrm{g} / \mathrm{ml}$ and $0.125 \mu \mathrm{g} / \mathrm{ml}, 1$ at $0.25 \mu \mathrm{g} / \mathrm{ml}$ and $<0.125 \mu \mathrm{g} / \mathrm{ml}, 16$ at $1 \mu \mathrm{g} / \mathrm{ml}$ and 21 at $0.5 \mu \mathrm{g} / \mathrm{ml}$ and MIC for Levofloxacin was 0 at $8 \mu \mathrm{g} / \mathrm{ml}, 0.25 \mu \mathrm{g} / \mathrm{ml}$ and $0.125 \mu \mathrm{g} / \mathrm{ml}, 1$ at $4 \mu \mathrm{g} / \mathrm{ml}, 3$ at $<0.125 \mu \mathrm{g} / \mathrm{ml}, 8$ at $1 \mu \mathrm{g} / \mathrm{ml}, 13$ at $0.5 \mu \mathrm{g} / \mathrm{ml}$ and 14 at $2 \mu \mathrm{g} / \mathrm{ml}$.

Since its introduction in 1948, chloramphenicol has been the treatment of choice for typhoid fever and remains the standard against which newer antimicrobials are compared. Treatment with chloramphenicol reduces mortality due to typhoid fever from about 20 to 1 per cent and the duration of fever from 14-28 days to 3-5 days16. However, chloramphenicol therapy has been associated with the emergence of resistance to chloramphenicol[6], a high relapse rate, bone marrow toxicity and high mortality rates in a recent study reported from the developing world. In our study Salmonella sp. remained sensitive to chloramphenicol, ampicillin, and co-trimoxazol. Quinolones may remain effective despite in vitro resistance[7].

\section{Conclusion}

Considering the rapid and increased emergence of high-level ciprofloxacin resistance, attempts should be made to explore the possibility of alternate antimicrobial therapy for successful treatment of enteric fever[8]. In conclusion, for optimal interpretation of susceptibility, quinolone MIC is needed in cases of enteric fever where nalidixic acid is reported resistant. Azithromycin resistance is emerging. However, chloramphenicol, cotrimoxazole and ampicillin have re-emerged as valuable oral options and ceftriaxone remains a viable parenteral option for treatment of typhoid in India[9]. 


\section{Reference}

[1]. Mad1. hulika U, Harish BN, Parija SC. Current pattern in antimicrobial susceptibility of Salmonella Typhi isolates in Pondicherry. Indian J Med Res; 120 : 111-4. (2004)

[2]. Effa EE, Bukirwa H. Azithromycin for treating uncomplicated 3. typhoid and paratyphoid fever (enteric fever). Cochrane Database Syst Rev; (4) : CD006083. (2008)

[3]. Menezes GA, Harish BN, Khan MA, Goessens WH, Hays 4. JP. Antimicrobial resistance trends in blood culture positive Salmonella Typhi isolates from Pondicherry, India, 2005-2009. Clin Microbiol Infect; 18 : 239-45. (2012)

[4]. Harish BN, Menezes GA. Preserving efficacy of 5. chloramphenicol against typhoid fever in a tertiary care hospital, India. Reg Health Forum; 15 : 92-6. (2011)

[5]. Dada-Adegbola HO, Muili KA. Antibiotic susceptibility pattern of urinary tract pathogens in Ibadan, Nigeria. Afr J Med Med Sci. ;39(3):173-179. (2010)

[6]. Brown N. M., Millar M. R., Frost J. A., Rowe B. Ciprofloxacin resistance in Salmonella paratyphi A. J. Antimicrob. Chemother.33:1258-1259. (1994)

[7]. Chitnis V., Chitnis D., Verma S., Hemvani N. Multidrug-resistant Salmonella typhi in India. Lancet 354:514-515. (1999)

[8]. Herikstad H., Hayes P., Mokhtar M., Fracaro M. L., Threlfall E. J.,Angulo F. J. Emerging quinolone-resistant Salmonella in the United States. Emerg. Infect. Dis. 3:371-372. (1997)

[9]. National Committee for Clinical Laboratory Standards Method for dilution antimicrobial susceptibility tests for bacteria that grow aerobically. Approved standard M7-A5. (National Committee for Clinical Laboratory Standards, Wayne, Pa). (2000) 